\title{
Cadophora luteo-olivacea isolated from apple (Malus domestica) fruit with post-harvest side rot symptoms in northern Italy
}

\author{
Greice Amaral Carneiro • Magdalena Walcher • \\ Sanja Baric (1)
}

Accepted: 18 September 2021 / Published online: 17 October 2021

(C) The Author(s) 2021

\begin{abstract}
Recently, Cadophora luteo-olivacea has been reported as a post-harvest pathogen of side rot of apple (Malus domestica) in Latvia, and of pear (Pyrus communis) in Italy and the Netherlands. In 2018 and 2019, in South Tyrol (northern Italy) 11 fungal cultures, identified as C. luteo-olivacea based on ITS (internal transcribed spacer region) sequence data, were obtained from apple fruit displaying postharvest side rot symptoms. The fruit were sampled in packinghouses representing different apple growing areas of South Tyrol. For a more accurate taxonomic assignment, two additional molecular genetic loci, $\beta$-tubulin (TUB2) and translation elongation factor $1 \alpha(\mathrm{TEF}-1 \alpha)$, of seven isolates were amplified and sequenced. Phylogenetic analysis based on multi-locus DNA sequence data confirmed that isolates from apple fruit with side rot symptoms indeed represented $C$. luteo-olivacea. A pathogenicity test performed on apple fruit of 'Golden Delicious' confirmed the virulence of a representative isolate. So far, C. luteo-olivacea represents a minor post-harvest pathogen of apple but considering the losses that this
\end{abstract}

Supplementary Information The online version contains supplementary material available at https://doi. org/10.1007/s10658-021-02388-4.

G. Amaral Carneiro $\cdot$ M. Walcher $\cdot$ S. Baric $(\bowtie)$

Faculty of Science and Technology, Free

University of Bozen-Bolzano, Universitätsplatz 5,

39100 Bozen-Bolzano, Italy

e-mail:sanja.baric@unibz.it fungus can cause to other crops, the awareness about this potential apple disease should be raised.

Keyword Fruit rot; fungal plant pathogens; emerging plant diseases; multi-locus sequence typing; molecular genetic identification

Modern apple cultivars generally show exceptional storage properties as fruit can be stored for a period of up to twelve months at low temperatures and under controlled atmosphere conditions (Sutton et al., 2014). During this process, fruit may deteriorate, which is caused by post-harvest physiological disorders or by diseases (Snowdon, 1990). The main postharvest diseases of pome fruits are caused by various fungal pathogens and in terms of economic losses, blue mold (Penicillium spp.), gray mold (Botrytis cinerea), bull's eye rot (Phlyctema vagabunda) and brown rot (Monilinia spp.) are regarded as the most important (Spadaro et al., 2019). Side rot of apple and pear has been considered a minor post-harvest disease, although it occasionally causes considerable economic damages on pears (Pyrus communis) in the Pacific Northwest USA and in Europe (Sugar, 2014). The principal pathogen associated with this disease is Cadophora malorum (Kidd and Beaumont) W. Gams (syns. Phialophora malorum [Kidd and Beaumont] McColloch, Sporotrichum malorum Kidd and Beaumont, and Sporotrichum carpogenum Rühle) (Spadaro et al., 2019). Bertrand et al. (1977) 
described an outbreak of lateral rot on 'Bosc' pears in Oregon (USA), suggesting that $C$. malorum probably entered the host through lenticels or micro-wounds in the cuticle. Sugar and Spotts (1993a) postulated that spores of the fungus may be brought into commercial packinghouses on the surface of fruit or on harvest bins, and that the inoculum is transmitted to unaffected fruit through immersion dump tanks. Recently, Cadophora luteo-olivacea (J.F.H. Beyma) T.C. Harr. and McNew, has been revealed as a postharvest pathogen of side rot on apple in Latvia, and on pear in Italy and the Netherlands (Grantina-Ievina, 2015; Spadaro et al., 2011; Wenneker et al., 2016). On pear fruit, C. luteo-olivacea and C. malorum were described to induce similar symptoms, which are manifested as dark brown circular to oval lesions that appear after about three, six or more months of cold storage (Spadaro et al., 2019; Sugar, 2014; Wenneker et al., 2016). Lesion diameters described on pear fruit caused by C. luteo-olivacea ranged from 0.5 to $1.0 \mathrm{~cm}$ (Wenneker et al., 2016), and those caused by C. malorum were less than $2 \mathrm{~cm}$ (Sugar, 2014).

South Tyrol is situated in the northern part of Italy and contributes to approximately $10 \%$ of the European apple production (Autonomous Province of Bozen-Bolzano, 2020). A survey on post-harvest pathogens was performed in 2018 and 2019 in packinghouses located in different parts of the apple production area of South Tyrol (Amaral Carneiro $\&$ Baric, 2021a). Apple fruit with symptoms resembling side rot were found in $1 \%$ of the decayed fruit samples. In fact, these fruit that were stored for five to eight months under controlled atmosphere conditions showed symptoms that could be assigned to two categories (Fig. 1). On some apple fruit, the lesions were circular and slightly sunken, with a black center or black spots scattered over the lesion and resembled those of black rot caused by Alternaria spp. (Spadaro et al., 2019). In other cases, the symptoms were manifested as circular, flat to slightly sunken lesions, and the rotten tissue remained rather firm. The color of such lesions ranged from brown to dark brown and could be confused with bull's eye rot as described by Sugar (2014) (Fig. 1B). In most of the cases, the lesion diameter was larger than $1 \mathrm{~cm}$ and reached up to approximately $4 \mathrm{~cm}$. In general, the diseased tissue was spongy (Fig. 1A and Supplementary Figure S1).

From all explants of ten out of eleven apple fruit showing the above-described symptoms, the fungus Cadophora spp. was obtained on Potato Dextrose Agar (PDA; VWR International, Milan, Italy) in pure culture (Table 1, Fig. 1 and Supplementary

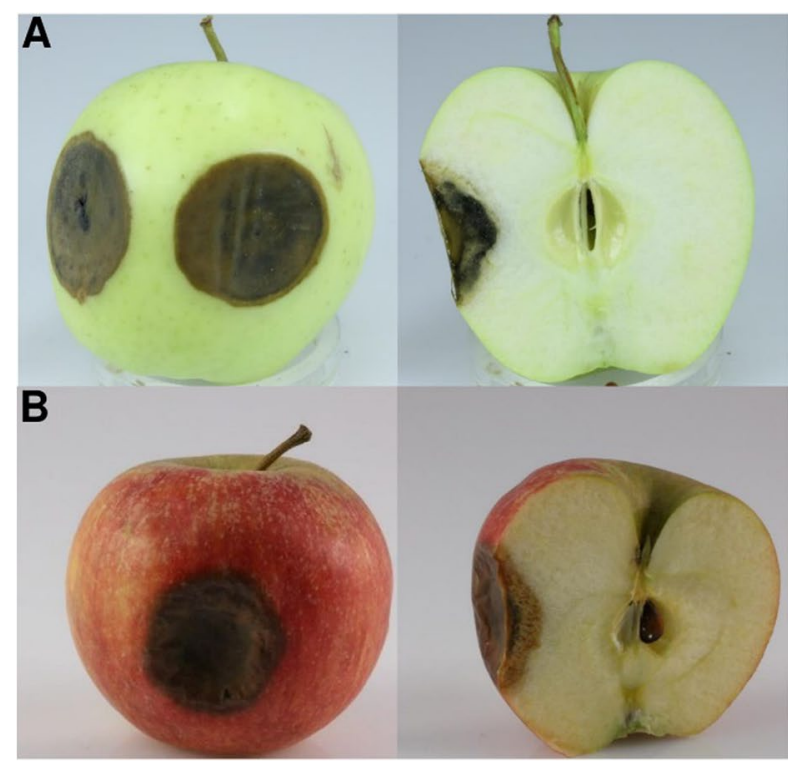

Fig. 1 The external and internal symptoms associated with side rot of apple after cold storage under controlled atmosphere conditions and the corresponding fungal isolates obtained on

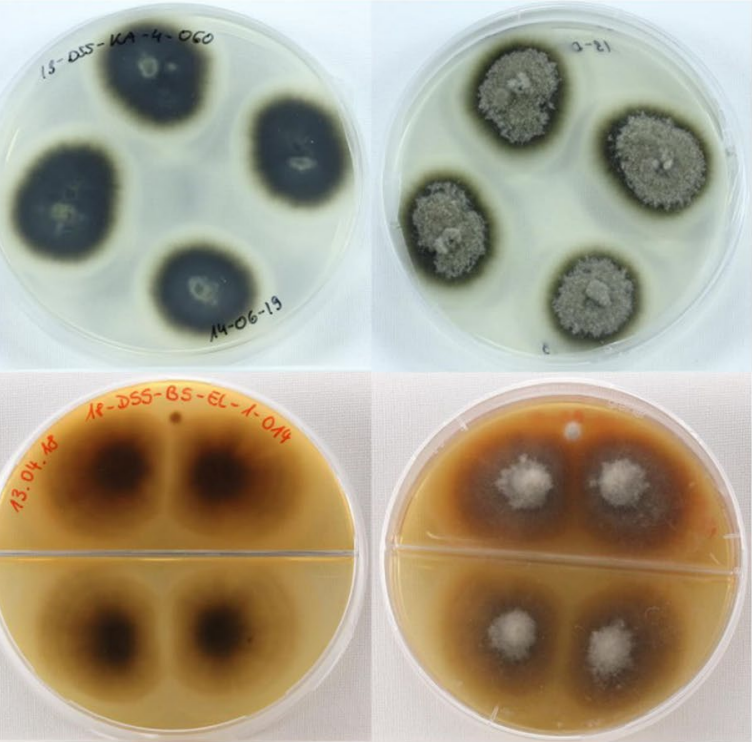

PDA. A: 'Golden Delicious' (19-DSS-KA-4-060) after eight months of storage and B: 'Roho 3615 '/Evelina ${ }^{\circledR}$ (18-DSS-BSEL-1-014) after five months of storage 
Table 1 Cadophora luteo-olivacea isolates obtained from decayed apple fruit that were sampled in different packinghouses in 2018 and 2019 in South Tyrol (northern Italy)

\begin{tabular}{|c|c|c|c|c|c|c|c|c|c|}
\hline \multirow[b]{2}{*}{ No } & \multirow[b]{2}{*}{ Isolate code } & \multirow[b]{2}{*}{$\begin{array}{l}\text { Fungal spe- } \\
\text { cies }\end{array}$} & \multirow[b]{2}{*}{$\begin{array}{l}\text { Apple cul- } \\
\text { tivar }\end{array}$} & \multirow[b]{2}{*}{$\begin{array}{l}\text { Year of } \\
\text { sampling }\end{array}$} & \multirow[b]{2}{*}{$\begin{array}{l}\text { Cultivation } \\
\text { method }\end{array}$} & \multirow[b]{2}{*}{$\begin{array}{l}\text { Growing } \\
\text { area }\end{array}$} & \multicolumn{3}{|c|}{ GenBank accession number } \\
\hline & & & & & & & ITS & TUB2 & TEF- $1 \alpha$ \\
\hline 1 & $\begin{array}{c}\text { 18-DSS-BS- } \\
\text { EL-1-014 }\end{array}$ & $\begin{array}{l}\text { C. luteo- } \\
\text { olivacea }\end{array}$ & $\begin{array}{l}\text { 'Roho } \\
\text { 3615'/Eve- } \\
\text { lina }{ }^{\circledR}\end{array}$ & 2018 & Organic & $\begin{array}{l}\text { Terlan/ } \\
\text { Andrian- } \\
\text { Terlano/ } \\
\text { Andriano }\end{array}$ & MZ144208 & - & - \\
\hline 2 & $\begin{array}{l}\text { 18-DSS- } \\
\text { CAFA-2-001 }\end{array}$ & $\begin{array}{l}\text { C. luteo- } \\
\quad \text { olivacea }\end{array}$ & $\begin{array}{l}\text { 'Granny } \\
\text { Smith' }\end{array}$ & 2018 & Integrated & $\begin{array}{l}\text { Meran- } \\
\text { Merano }\end{array}$ & MZ144207 & MZ269721 & MZ269727 \\
\hline 3 & $\begin{array}{l}\text { 18-DSS- } \\
\text { KA-1-020 }\end{array}$ & $\begin{array}{l}\text { C. luteo- } \\
\text { olivacea }\end{array}$ & 'Braeburn' & 2018 & Integrated & $\begin{array}{l}\text { Unterland- } \\
\text { Bassa } \\
\text { Atesina }\end{array}$ & MZ144210 & MZ269717 & MZ269730 \\
\hline 4 & $\begin{array}{l}\text { 18-DSS- } \\
\text { KA-2-057 }\end{array}$ & $\begin{array}{l}\text { C. luteo- } \\
\text { olivacea }\end{array}$ & 'Braeburn' & 2018 & Integrated & $\begin{array}{l}\text { Unterland- } \\
\text { Bassa } \\
\text { Atesina }\end{array}$ & MZ144206 & - & - \\
\hline 5 & $\begin{array}{l}\text { 18-DSS- } \\
\text { MX-1-130 }\end{array}$ & $\begin{array}{l}\text { C. luteo- } \\
\text { olivacea }\end{array}$ & $\begin{array}{l}\text { 'Red Deli- } \\
\text { cious' }\end{array}$ & 2018 & Integrated & $\begin{array}{l}\text { Eisacktal- } \\
\text { Valle } \\
\text { Isarco }\end{array}$ & MZ144205 & - & - \\
\hline 6 & $\begin{array}{l}\text { 18-DSS- } \\
\text { NTC-1-004 }\end{array}$ & $\begin{array}{l}\text { C. luteo- } \\
\text { olivacea }\end{array}$ & $\begin{array}{r}\text { 'SQ 159'/ } \\
\text { Natyra® }\end{array}$ & 2018 & Organic & $\begin{array}{l}\text { Unterland- } \\
\text { Bassa } \\
\text { Atesina }\end{array}$ & MZ144211 & - & - \\
\hline 7 & $\begin{array}{l}\text { 19-DSS- } \\
\text { BS-3-012 }\end{array}$ & $\begin{array}{l}\text { C. luteo- } \\
\text { olivacea }\end{array}$ & $\begin{array}{l}\text { 'Roho } \\
3615 \text { '/Eve- } \\
\text { lina }{ }^{\circledR}\end{array}$ & 2019 & Organic & $\begin{array}{l}\text { Überetsch- } \\
\text { Oltradige }\end{array}$ & MZ144204 & MZ269719 & MZ269728 \\
\hline 8 & $\begin{array}{l}\text { 19-DSS- } \\
\text { BS-3-014 }\end{array}$ & $\begin{array}{l}\text { C. luteo- } \\
\text { olivacea }\end{array}$ & $\begin{array}{l}\text { 'Roho } \\
3615 \text { '/Eve- } \\
\text { lina }{ }^{\circledR}\end{array}$ & 2019 & Organic & $\begin{array}{l}\text { Überetsch- } \\
\text { Oltradige }\end{array}$ & MZ144209 & MZ269723 & MZ269729 \\
\hline 9 & $\begin{array}{l}\text { 19-DSS- } \\
\text { KA-4-044 }\end{array}$ & $\begin{array}{l}\text { C. luteo- } \\
\text { olivacea }\end{array}$ & $\begin{array}{l}\text { 'Golden } \\
\text { Delicious' }\end{array}$ & 2019 & Integrated & $\begin{array}{l}\text { Unterland- } \\
\text { Bassa } \\
\text { Atesina }\end{array}$ & MZ144203 & MZ269718 & MZ269724 \\
\hline 10 & $\begin{array}{l}\text { 19-DSS- } \\
\text { KA-4-060 }\end{array}$ & $\begin{array}{l}\text { C. luteo- } \\
\text { olivacea }\end{array}$ & $\begin{array}{l}\text { 'Golden } \\
\text { Delicious' }\end{array}$ & 2019 & Integrated & $\begin{array}{l}\text { Unterland- } \\
\text { Bassa } \\
\text { Atesina }\end{array}$ & MZ144202 & MZ269722 & MZ269726 \\
\hline 11 & $\begin{array}{l}\text { 19-DSS- } \\
\text { MX-2-015 }\end{array}$ & $\begin{array}{l}\text { C. luteo- } \\
\text { olivacea }\end{array}$ & $\begin{array}{l}\text { 'Granny } \\
\text { Smith' }\end{array}$ & 2019 & Integrated & $\begin{array}{l}\text { Eisacktal- } \\
\text { Valle } \\
\text { Isarco }\end{array}$ & MZ144201 & MZ269720 & MZ269725 \\
\hline
\end{tabular}

Figure S1). In one case, sample 19-DSS-MX-2-015, Cadophora spp. was isolated in conjunction with Phlyctema vagabunda (syn. Neofabraea alba) but could be separated in pure culture in a subsequent step. The fungal isolates on PDA were flat, felty and cottony in the center, with smooth margins, an even edge, and they varied in color from white to gray or black-olivaceous (see Fig. 1 and Supplementary Figure S1).

Pure single-spore cultures were obtained (Amaral Carneiro \& Baric, 2021b) and DNA was extracted from approximately $100 \mathrm{mg}$ of fresh mycelium of each fungal isolate following the protocol of Cassago et al. (2002). The first molecular genetic identification was based on DNA sequencing of the internal transcribed spacer (ITS) region with the primer pairs UN-UP18S42/UN-LO28S22 (Lévesque \& De Cock, 2004). Further PCR reactions with the primer pairs BT-CadF/BT-CadR (Travadon et al., 2015), EF1-728F/EF1-986R (Carbone \& Kohn, 1999) and EF1-688F/EF1-1251R (Alves et al., 2008) were performed to amplify segments of $\beta$-tubulin (TUB2) and translation elongation factor 1a (TEF-1a), respectively. Each PCR reaction contained 7.5 
$\mu \mathrm{L}$ of the 2x PCRBIO Taq Mix (PCR Biosystems Ltd., Oxford, UK; containing a premix of Taq DNA polymerase, dNTPs and the appropriate buffer system), $0.75 \mu \mathrm{L}$ of each forward and reverse primer $(10 \mu \mathrm{M})$ and $5 \mu \mathrm{L}$ of sterile nuclease-free-water. The final volume of the PCR reaction of $15 \mu \mathrm{L}$ was reached by the addition of $1 \mu \mathrm{L}$ of template DNA (initial concentration of $10 \mathrm{ng} \mu \mathrm{L}^{-1}$ ). The PCR conditions for ITS, TUB2 and TEF- $1 \alpha$ were followed as described by Amaral Carneiro and Baric (2021a), Travadon et al. (2015) and Glass and Donaldson (1995), respectively. While the ITS region of all the fungal isolates could be successfully amplified, specific PCR products with primers BT-CadF/BT-CadR designed by Travadon et al. (2015) were obtained only for seven of the eleven fungal isolates. Furthermore, despite intensive efforts to optimize the PCR reaction, no amplicons were obtained with primer pair EF1-728F/EF1-986R. Instead, amplicons could be generated with primers EF1-688F/EF1-1251R for seven isolates, but primers EF1-728F and EF1986R were used as internal sequencing primers for the PCR products of the TEF- $1 \alpha$ region. PCR products purified with the A'SAPTM PCR clean-up reagents (ArticZymes, Troms $\varnothing$, Norway) were sent for Sanger sequencing to the company Microsynth Seqlab GmbH (Göttingen, Germany).

The quality of DNA sequences of the ITS region was checked with the software Geneious Prime version 2019.2 (Biomatters Ltd., Auckland, New Zealand), and each sequence was individually trimmed at the same position at either end, obtaining a final sequence length of $446 \mathrm{bp}$. The same procedure was applied to the seven TUB2 and TEF-1a sequences, resulting in final sequence lengths of $413 \mathrm{bp}$ and 355 to $363 \mathrm{bp}$, respectively. Subsequent BLAST analysis revealed that all the DNA sequences obtained in the present study showed the highest degree of similarity with sequences of the genus Cadophora contained in the GenBank database.

Pairwise distance matrices obtained separately for each genomic region and comprising DNA sequences of each isolate from South Tyrol revealed the presence of three different ITS haplotypes (ITS-a: 8
Fig. 2 Maximum-likelihood tree constructed with MEGA X software (Kumar et al., 2018) based on a multi-locus alignment (ITS, TUB2 and TEF-1a) with 1,247 characters. C. luteoolivacea isolates associated with side rot of apple in South Tyrol (highlighted in bold) and 18 reference isolates representing different species of the genus from the study of Travadon et al. (2015) were included in the analysis. C. finlandia was used as an outgroup. The numbers at the branches of the tree $(>95 \%)$ represent bootstrap values obtained after 1,000 replications

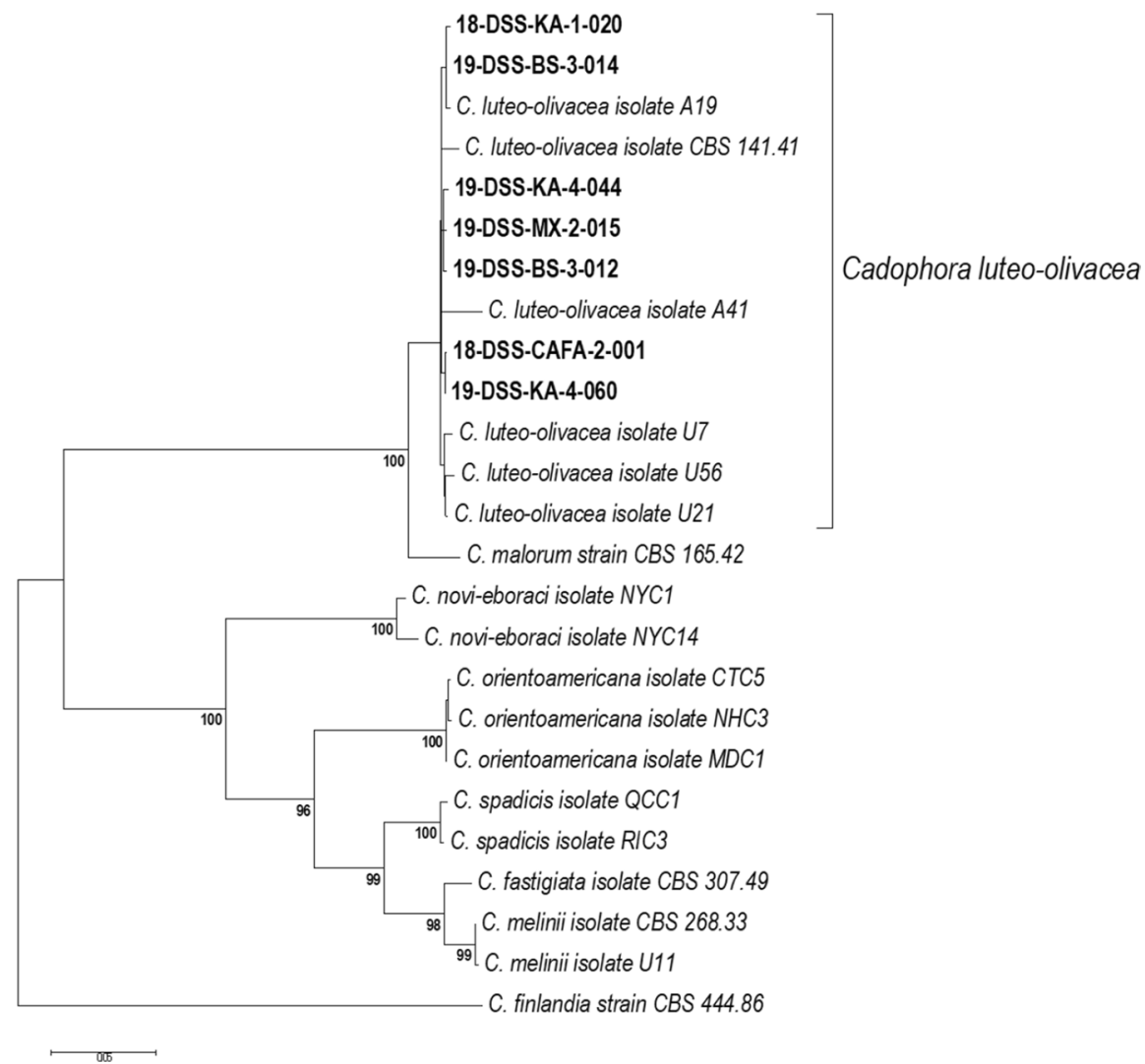


isolates, ITS-b: 1 isolate and ITS-c: 2 isolates). The haplotypes ITS-a and ITS-b differed in a single point mutation, while ITS-c differed from the others by two point mutations. The TUB2 sequences showed four different haplotypes (TUB2-a: 3 isolates, TUB2b: 2 isolates, TUB2-c: 1 isolate and TUB2-d: 1 isolate). TUB2-a differed from TUB2-b in a single point mutation, and from TUB2-c and TUB2-d by two point mutations. Regarding the DNA sequences of the TEF- $1 \alpha$ gene, three haplotypes were found (TEF$1 \alpha$-a: 3 isolates, TEF- $1 \alpha$-b: 3 isolates and TEF- $1 \alpha$-c: 1 isolate). The TEF-1 $\alpha$ segment showed the highest degree of variability among the investigated isolates compared to the sequences of the other two loci. TEF$1 \alpha$-a differed from TEF-1a-b by five point mutations, while TEF- $1 \alpha$-c differed from TEF- $1 \alpha$-a in 13 point mutations and from TEF- $1 \alpha-\mathrm{b}$ in 14 point mutations.

Sequences of the same set of genomic regions as analyzed in this study of 18 reference isolates representing different species of the genus Cadophora were selected from Travadon et al. (2015) to perform a phylogenetic analysis (Supplementary Table S1).
The phylogenetic analysis was based on an alignment comprising 1,247 positions of concatenated multilocus sequences and was accomplished using the maximum likelihood (ML) algorithm as implemented in the software Molecular Evolutionary Genetic Analysis (MEGA X) (Kumar et al., 2018). The resulting phylogenetic tree clustered all the isolates obtained in the present study in the monophyletic C. luteo-olivacea group (Fig. 2).

Phenotypic assessment based on in vitro growth rates and colony morphology, as well as conidia characteristics was conducted with pure singlespore cultures of representative isolates 18-DSSCAFA-2-001, 19-DSS-BS-3-014 and 19-DSSMX-2-015. The mycelium growth of these isolates after ten days at $20{ }^{\circ} \mathrm{C}$ showed an area of $5.2 \pm 0.5$, $6.1 \pm 0.3$ and $5.1 \pm 1.2 \mathrm{~cm}^{2}$, respectively. The shape of the conidia was cylindrical with round ends, with average length and width of $8.6 \pm 2.3 \times 2.6 \pm 0.8$, $9.4 \pm 1.4 \times 2.1 \pm 1.2 \mu \mathrm{m}$ and $8.4 \pm 2.5 \times 1.9 \pm 0.7 \mu \mathrm{m}$, respectively (Fig. 3).
Fig. 3 Colony appearance on the upper side (A) and reverse side (B) of isolate 18-DSSCAFA-2-001 grown on PDA medium at $20{ }^{\circ} \mathrm{C}$ for 10 days, and conidia at a magnification of $400 \times(\mathrm{C})$ and $1,000 \times(D)$. Scale Bar $=50 \mu \mathrm{m}$

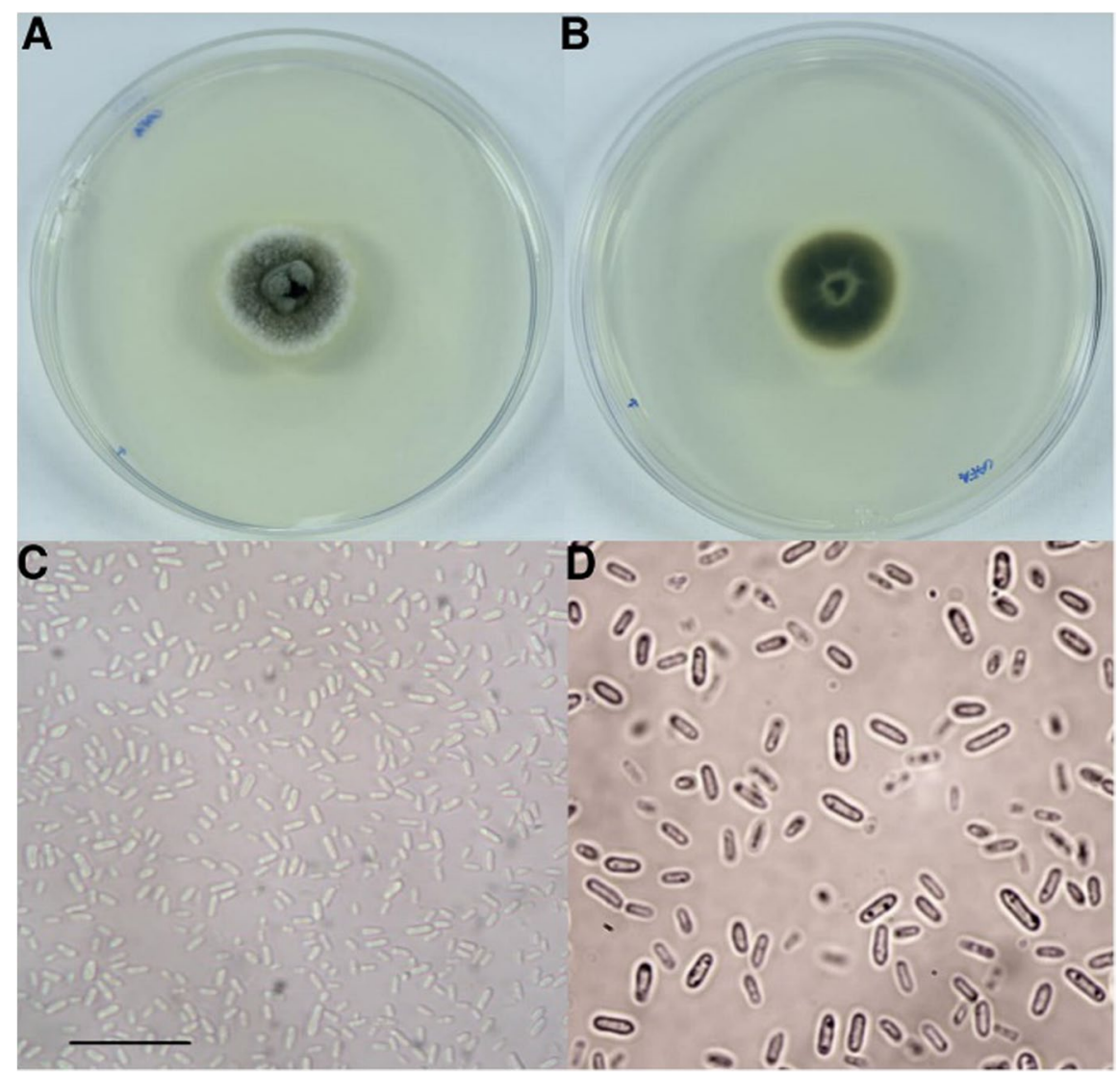


Koch's postulates were proven with isolate 18-DSS-CAFA-2-001 on twelve apple fruit of 'Golden Delicious'. Preparation of the conidia suspension adjusted to $10^{4}$ conidia $\mathrm{mL}^{-1}$ and inoculation of apple fruit were performed as described in Amaral Carneiro and Baric (2021a). Twelve control fruit were inoculated with sterile distilled water. Inoculated fruit were incubated for two weeks in moist chambers at $20{ }^{\circ} \mathrm{C}$ in the dark. The external symptoms were assessed, and the size of the lesions was measured. Isolate 18-DSS-CAFA-2-001 successfully infected $97 \%$ of the inoculated wounds $(\mathrm{N}=36)$. Lesions began to become evident at 5 days post-inoculation (dpi). At 21 dpi, the circular lesions had a dark-brown to black color and a diameter of $1.1 \pm 0.5 \mathrm{~cm}$ (Supplementary Figure S2). Re-isolates from the lesions showed identical phenotypic characteristics as those previously described, and DNA sequences of the ITS region confirmed their identity. No lesions or rot developed on the negative control fruit.

C. luteo-olivacea is a pathogen frequently associated with wood-decay of grapevine (Vitis vinifera), reported in Canada, South Africa, Spain, Uruguay, and USA (Gramaje et al., 2011; Halleen et al., 2007; Navarrete et al., 2011; Travadon et al., 2015; ÚrbezTorres et al., 2014). In 2011, Spadaro et al. detected and characterized $C$. luteo-olivacea as a causative agent of the post-harvest disease skin pitting of kiwifruit (Actinidia spp.) in several Italian packinghouses. Additionally, this species was reported as a post-harvest pathogen of grape and kiwifruit in cold climates such as Ibaraki prefecture (Japan) and central Chile, respectively (Nakaune et al., 2016; Auger et al., 2018). On pome fruits, C. luteo-olivacea was isolated from rotten apple fruit at storage sites in Latvia (Grantina-Ievina, 2015), and from a pear sample in Italy (Spadaro et al., 2011), while in the Netherlands, C. luteo-olivacea was found to be an important post-harvest pathogen of pear (Wenneker et al., 2016), but less abundant on apple (Köhl et al., 2018). A closely related species, $C$. malorum is the main casual organism associated with side rot of apple in the United States (McColloch, 1944; Sugar, 2014; Sugar \& Spotts, 1992, 1993a, 1993b).

Spadaro et al. (2011) suggested that C. luteo-olivacea could be a post-harvest pathogen of kiwi and pome fruit in Europe, while side rot of pome fruit in America is caused by C. malorum. However, this assumption is based on the analysis of a very small number of isolates (two of $C$. malorum; three of $C$. luteo-olivacea) and by considering ITS as the only molecular marker region, DNA sequences of which were not even available for all the isolates. The information available about $C$. malorum on pears in the United States mainly derives from the publications of David Sugar and co-workers (Sugar, 2014; Sugar \& Powers, 1986; Sugar \& Spotts, 1992, 1993a, 1993b), while only one study describing $C$. malorum as a post-harvest pathogen of apple was retrieved (McColloch, 1944). These works primarily focused on the description of symptoms caused by the pathogen and on morphological characteristics of the fungus in vitro. However, many studies have affirmed that the biological characteristics and morphological features of C. malorum and C. luteo-olivacea are very similar (Harrington \& McNew, 2003; Spadaro et al., 2011). Moreover, ITS sequence analysis does not permit to distinguish $C$. malorum and C. luteo-olivacea as distinct monophyletic groups. Therefore, it would be of interest to perform a multi-locus sequence typing analysis to ascertain whether all the isolates obtained in the past from apple and pear fruit with side rot symptoms in the USA would indeed cluster in the $C$. malorum group.

Blanchette et al. (2010), Travadon et al. (2015), and Eichmeier et al. (2020) have suggested that there is a relationship between environmental conditions and the distribution of Cadophora spp. Some species of the genus may be better adapted to cooler climates, as $C$. malorum was the main isolate obtained from degraded wood huts in Antarctica (Blanchette et al., 2010) or C. novi-eboraci was isolated from wood decay of grapevine in New York (Travadon et al., 2015), Germany (Gierl \& Fischer, 2017), and from walnut trees with cankers and dieback symptoms in the Czech Republic (Eichmeier et al., 2020). C. luteo-olivacea, in contrast, was suggested to have an apparent preference for warmer, Mediterranean climate, since it has been isolated primarily in California (Travadon et al., 2015), South Africa (Halleen et al., 2007), and Spain (Gramaje et al., 2011). However, this assumption contradicts the study of Köhl et al. (2018), which showed that C. luteo-olivacea commonly occurs in pear and apple orchards in the Netherlands. The genus Cadophora has received little attention in taxonomic studies, which raises questions about the accurate classification of some specimens in fungal culture collections and DNA sequence 
databases (Maciá-Vicente et al., 2020; Travadon et al., 2015). Therefore, an association of the distribution of different Cadophora species and environmental conditions seems to be premature.

There is little evidence available about $C$. luteoolivacea as a post-harvest pathogen causing side rot of domesticated apple (Malus domestica) in Italy. The only indication of the presence of C. luteo-olivacea on European crab apple in Italy dates to 1950, when the strain CBS 357.51 was isolated from Malus sylvestris in Bologna (Emilia-Romagna) and was deposited in the fungal culture collection CBSKNAW of the Fungal Biodiversity Centre (Utrecht, The Netherlands). So far, C. luteo-olivacea accounted for $1 \%$ of the isolates obtained from rotten apple fruit in our survey (see also Amaral Carneiro \& Baric, 2021a). Nevertheless, epidemiological investigations at different apple-growing sites in this region would be recommended to identify possible sources of inoculum, as the fungus can be found on different plant residues in the orchard (Köhl et al., 2018). Such studies would represent a precautionary measure to avoid a possible scenario observed on kiwifruit in northern and central Italy. After its emergence on this crop, C. luteo-olivacea was initially considered irrelevant, but developed into one of the most important post-harvest pathogens of kiwifruit within a decade (Gorini, 1991; Piano et al., 2001; Spadaro et al., 2011). Furthermore, Sugar and Powers (1986) confirmed, by examining wound colonization, that $C$. malorum was a weak pathogen, and was able to invade the fruit only when its competitor, Cladosporium herbarum, was controlled in the orchard with benomyl sprays to which $C$. malorum was shown to be resistant (Bertrand \& MacSwan, 1977). No such data are available for $C$. luteo-olivacea. Since there are no specific strategies implemented to control side rot of apple in this geographic area, it would be important to conduct fungicide sensitivity assays with products authorized in integrated pest management (Workgroup for Integrated Fruit Production in South Tyrol, 2021) and organic production, to determine whether the existing fungicide programs could also help preventing the development of $C$. luteo-olivacea.

Acknowledgements We are grateful to the Free University of Bozen-Bolzano for funding the research project. Furthermore, we would like to thank the South Tyrolean Fruit Growers Cooperatives for providing samples of apple fruit with postharvest diseases. The authors thank the Department of Innovation, Research, University andMuseums of the Autonomous Province of Bozen/Bolzano for covering the Open Access publication costs.

Funding The research project "Development of a decision support system for the determination of post-harvest disorders and diseases of apples - DSSApple" was funded by the Free University of Bozen-Bolzano (Project Code IN2067-ID Call 2017).

Data availability All DNA sequences obtained in the present study were deposited in GenBank, whereas the multilocus DNA sequence alignment was submitted to TreeBASE (study accession number S28299; http://purl.org/phylo/ treebase/phylows/study/TB2:S28299).

Consent for publication Publication has been approved by all co-authors.

Conflicts of interest/Competing interests The authors declare that they have no conflict of interest.

Open Access This article is licensed under a Creative Commons Attribution 4.0 International License, which permits use, sharing, adaptation, distribution and reproduction in any medium or format, as long as you give appropriate credit to the original author(s) and the source, provide a link to the Creative Commons licence, and indicate if changes were made. The images or other third party material in this article are included in the article's Creative Commons licence, unless indicated otherwise in a credit line to the material. If material is not included in the article's Creative Commons licence and your intended use is not permitted by statutory regulation or exceeds the permitted use, you will need to obtain permission directly from the copyright holder. To view a copy of this licence, visit http://creativecommons.org/licenses/by/4.0/.

\section{References}

Alves, A., Crous, P. W., Correia, A., \& Phillips, A. J. L. (2008). Morphological and molecular data reveal cryptic speciation in Lasiodiplodia theobromae. Fungal Diversity, 28, $1-13$.

Amaral Carneiro, G., \& Baric, S. (2021a). Colletotrichum fioriniae and $C$. godetiae causing postharvest bitter rot of apple in South Tyrol (northern Italy). Plant Disease. https://doi.org/10.1094/PDIS-11-20-2482-RE. First look.

Amaral Carneiro, G., \& Baric, S. (2021b). Single-spore isolation protocol for characterisation of postharvest pathogens causing bitter rot of apple in South Tyrol. Acta Horticulturae (in press).

Auger, J., Pérez, I., Osorio-Navarro, C., \& Esterio, M. (2018). First report of Cadophora luteo-olivacea causing side rot on kiwifruit in Chile. Plant Disease, 102(3), 680. 
Bertrand, P., \& MacSwan, I. (1977). Control of postharvest decay in Oregon tree fruit crops. Proceedings of the Oregon Horticultural Society, 68, 71-73.

Bertrand, P. F., MacSwan, I. C., Rackham, R. L., \& Moore, B. J. (1977). An outbreak of side rot in Bosc pears in Oregon. Plant Disease Reporter, 61, 890-893.

Blanchette, R. A., Held, B. W., Arenz, B. E., Jurgens, J. A., Baltes, N. J., Duncan, S. M., \& Farrell, R. L. (2010). An antarctic hot spot for fungi at Shackleton's historic hut on Cape Royds. Microbial Ecology, 60(1), 29-38.

Carbone, I., \& Kohn, L. M. (1999). A method for designing primer sets for speciation studies in filamentous ascomycetes. Mycologia, 91(3), 553-556.

Cassago, A., Panepucci, R. A., TortellaBaião, A. M., \& Henrique-Silva, F. (2002). Cellophane based mini-prep method for DNA extraction from the filamentous fungus Trichoderma reesei. BMC Microbiology, 2, 14.

Eichmeier, A., Pecenka, J., Spetik, M., Necas, T., Ondrasek, I., Armengol, J., León, M., Berlanas, C., \& Gramaje, D. (2020). Fungal trunk pathogens associated with Juglans regia in the Czech Republic. Plant Disease, 104(3), 761-771.

Gierl, L., \& Fischer, M. (2017). Grapevine trunk disease in German viticulture II. Associated fungi occurring on nonVitis hosts, and first report of Phaeoacremonium angustius. Vitis, 56(3), 103-110.

Glass, N. L., \& Donaldson, G. C. (1995). Development of primer sets designed for use with the PCR to amplify conserved genes from filamentous ascomycetes. Applied and Environmental Microbiology, 61(4), 1323-1330.

Gorini, F. (1991). Skin pitting of kiwifruit during storage. Acta Horticulturae, 297, 595-598.

Gramaje, D., Mostert, L., \& Armengol, J. (2011). Characterization of Cadophora luteo-olivacea and C. melinii isolates obtained from grapevines and environmental samples from grapevine nurseries in Spain. Phytopathologia Mediterranea, 50, 112-126.

Grantina-Ievina, L. (2015). Fungi causing storage rot of apple fruit in integrated pest management system and their sensitivity to fungicides. Rural Sustainability Research, 34(329), 2-11.

Halleen, F., Mostert, L., \& Crous, P. W. (2007). Pathogenicity testing of lesser-known vascular fungi of grapevines. Australasian Plant Pathology, 36(3), 277-285.

Harrington, T. C., \& McNew, D. L. (2003). Phylogenetic analysis places the Phialophora-like anamorph genus Cadophora in the Helotiales. Mycotaxon, 87, 141-151.

Köhl, J., Wenneker, M., Groenenboom-de Haas, B. H., Anbergen, R., Goossen-van de Geijn, H. M., Lombaers-van der Plas, C. H., Pinto, F. A. M. F., \& Kastelein, P. (2018). Dynamics of post-harvest pathogens Neofabraea spp. and Cadophora spp. in plant residues in Dutch apple and pear orchards. Plant Pathology, 67(6), 1264-1277.

Kumar, S., Stecher, G., Li, M., Knyaz, C., \& Tamura, K. (2018). MEGA X: Molecular evolutionary genetics analysis across computing platforms. Molecular Biology and Evolution, 35(6), 1547-1549.

Lévesque, C.A., \& De Cock, A.W.A.M. (2004) . Molecular phylogeny and taxonomy of the genus Pythium. Mycological Research, 108, 1363-1388.
Maciá-Vicente, J. G., Piepenbring, M., \& Koukol, O. (2020). Brassicaceous roots as an unexpected diversity hot-spot of helotialean endophytes. IMA Fungus, 11(1), 1-23.

McColloch, L. P. (1944). A study of the apple rot fungus, Phialophora malorum. Mycologia, 36, 576-590.

Nakaune, R., Tatsuki, M., Matsumoto, H., \& Ikoma, Y. (2016). First report of a new postharvest disease of grape caused by Cadophora luteo-olivacea. Journal of General Plant Pathology, 82(2), 116-119.

Navarrete, F., Abreo, E., Martínez, S., Betucci, L., \& Lupo, S. (2011). Pathogenicity and molecular detection of Uruguayan isolates of Greeneria uvicola and Cadophora luteo-olivacea associated with grapevine trunk diseases. Phytopathologia Mediterranea, 50, S166-S175.

Piano, S., Gilardi, G., Galliano, A., \& Gullino, M. L. (2001). Gravi attacchi di Phialophora sp. su frutti di actinidia. Informatore Fitopatologico, 51(9), 76.

Snowdon, A. L. (1990). A colour atlas of post-harvest diseases and disorders of fruits and vegetables. Volume 1: General Introduction and Fruits. London: Wolfe Publishing.

Spadaro, D., Pellegrino, C., Garibaldi, A., \& Gullino, M. L. (2011). Development of SCAR primers for the detection of Cadophora luteo-olivacea on kiwifruit and pome fruit and of Cadophora malorum on pome fruit. Phytopathologia Mediterranea, 50(3), 430-441.

Spadaro, D., Torres, R., Errampalli, D., Everett, K., Ramos, L., \& Mari, M. (2019). Postharvest diseases of pome fruit. In L. Palou, \& J. L. Smilanick (Eds.), Postharvest Pathology of Fresh Horticultural Produce (1st ed., pp. 55-109). Boca Raton, Florida: CRC Press.

Sugar, D. (2014). Side rot. In T. B. Sutton, H. S. Aldwinckle, A. M. Agnello, \& J. F. Walgenbach (Eds.), Compendium of apple and pear diseases and pests (2nd ed., pp. 81-82). St. Paul, MN: The American Phytopathological Society.

Sugar, D., \& Powers, K. (1986). Interactions among fungi causing postharvest decay of pear. Plant Disease, 70, 1132-1134.

Sugar, D., \& Spotts, R. A. (1992). Sources of inoculum of Phialophora malorum, causal agent of side rot of pear. Phytopathology, 82, 735-738.

Sugar, D., \& Spotts, R. A. (1993a). Dispersal of inoculum of Phialophora malorum in pear orchards and inoculum redistribution in pear immersion tanks. Plant Disease, 77, 47-49.

Sugar, D., \& Spotts, R. A. (1993b). The importance of wounds in infection of pear fruit by Phialophora malorum and the role of hydrostatic pressure in spore penetration of wounds. Phytopathology, 83, 1083-1086.

Sutton, T. B., Aldwinckle, H. S., Agnello, A. M., \& Walgenbach, J. F. (2014). Compendium of apple and pear diseases and pests (2nd ed.). St. Paul, MN: The American Phytopathological Society.

Travadon, R., Lawrence, D. P., Rooney-Latham, S., Gubler, W. D., Wilcox, W. F., Rolshausen, P. E., \& Baumgartner, K. (2015). Cadophora species associated with wood-decay of grapevine in North America. Fungal Biology, 119(1), 53-66.

Úrbez-Torres, J. R., Haag, P., Bowen, P., \& O'Gorman, D. T. (2014). Grapevine trunk diseases in British Columbia: Incidence and characterization of the fungal pathogens 
associated with black foot disease of grapevine. Plant Disease, 98(4), 456-468.

Wenneker, M., Pham, K. T. K., Lemmers, M. E. C., de Boer, F. A., van Leeuwen, P. J., Hollinger, T. C., Groenenboom-de Haas, B. H., \& Köhl, J. (2016). First report of Cadophora luteo-olivacea causing side rot on 'Conference' pears in the Netherlands. Plant Disease, 100(10), 2162.
Workgroup for Integrated Fruit Production in South Tyrol. (2021). Guidelines for the integrated cultivation of pome fruits 2021. AGRIOS, Terlan-Terlano. http://www.agrios. it/wp-content/uploads/Guidelines-AGRIOS-2021-1.pdf. Retrieved Mar 142021. 